\title{
Does Leadership Style Influence Organizational Effectiveness in Non-Governmental Organizations?
}

\author{
Grace Mwai ${ }^{1}$, Juliana Namada ${ }^{1} \&$ Paul Katuse ${ }^{1}$ \\ ${ }^{1}$ Chandaria School of Business, United States International University-Africa, Nairobi, Kenya \\ Correspondence: Grace Mwai, Chandaria School of Business, United States International University-Africa \\ Nairobi, Kenya. E-mail: gracemwaidba@gmail.com
}

Received: May 16, 2018

doi:10.5539/ijbm.v13n8p52
Accepted: June 18, 2018

Online Published: June 30, 2018

\begin{abstract}
This article examines the influence of leadership style on organizational effectiveness. Research design used was explanatory and descriptive. The population of the study was project managers of 5547 NGOs registered in Kenya in the year 2016. The data collection tool was a questionnaire. The study sample size was 374 project managers from NGOs in Kenya. Data was analyzed using descriptive and inferential statistical methods. The descriptive statistics methods used included mean, standard deviation and variance, while the inferential statistics used in the study included analysis of variance (ANOVA), and standardized coefficients. Leadership style construct is in three parameters: Clear instructions, concern for employees, and employee consultation. The construct parameters of organizational effectiveness are organization goals attainment, stakeholder satisfaction, and process efficiency. The linear regression model results explain 15.1 percent of the variation in organizational effectiveness and the 84.9 percent from error term and variables not examined in this research. The $\mathrm{F}$ statistic was 49.875 at $\mathrm{P}$ value of 0.000 , meaning that the leadership style has a significant influence on organizational effectiveness. Clear instructions significantly and positively influenced the attainment of organizational goals $(p=0.001)$. Concern for employees was found to significantly and positively facilitate the attainment of organizational goals $(p=0.009)$ and significantly and negatively influence stakeholder satisfaction $(p=0.006)$. In addition, concern for employees significantly and negatively influenced organizational process efficiency $(\mathrm{p}=0.009)$. The study recommends that leaders in an organization should provide distinct instructions and be concerned about employees to achieve process efficiency and goal attainment.
\end{abstract}

Keywords: leadership, leadership style, organization, organizational effectiveness, path goal

\section{Introduction}

Organizations often aim to be successful by prioritizing strategy development and implementation as a critical task, given the turbulent business environments they operate in (Pearce \& Robinson, 2013). An organization that meets its core business strategies, goals and objectives is effective (Yukl, 2008). Organizational effectiveness therefore points towards effective, prudent and strategic use of all the organizational resources, which include human, financial and technological resources for creating competitive advantage (Daft, 2010). Yukl (2008) asserts, an organization's effectiveness is its capability to meet its set vision and mission given the resources in its possession. NGOs are defined as private, nonprofit-making organizations that aim to serve societal interests by focusing advocacy and or operational efforts on social, political and economic goals, including equity, education, health, environmental protection and human rights (Teegen, Doh, \&Vachani, 2004)

\subsection{Problem Statement}

The current global environment for NGOs is defined by fundraising uncertainties, effects of climate change, increased economic inequalities, changing geopolitical dynamics, and greater interconnectivity using the internet and leading to the "one world approach" (Green, 2015). A study by Bagire, Aosa and Awino (2012) on the relations of three factors in NGOs in Uganda, NGO structure, leadership personal factors, and performance implications concluded that performance measurement in NGOs was a multidimensional construct often consisting of intangibility of services, differing internal practices, unknown outcomes, and different stakeholder interests.

A review of related literature indicates that level of strategic planning implementation had a positive relationship 
on organizational effectiveness on social service organizations in Portugal (Ferreira \& Proenca, 2015). Strategy implementation drivers influencing project effectiveness in NGOs were leadership, culture, resources allocation, and structure (Ramadan, 2015). In addition, organizational size and donor policies were recommended as mediating variables for future research in the latter study, which focused on the impact of strategy implementation drivers on project effectiveness in Warsaw, Poland. Supportive leadership and availability of adequate funds were the two most essential determinants of the sustainability of local NGOs in Ghana (Okorley \& Nkrumah, 2012), a research that also suggested leadership style and resources as significant variables to examine in the sustainability of NGOs. These studies gave impetus to study the influence of leadership styles on organizational effectiveness, with a context of NGOs registered in Kenya.

\subsection{Hypothesis and Significance}

The purpose of this study was to examine the influence of leadership style on organizational effectiveness of NGOs in Kenya. For the purposes of this research, organizational effectiveness, the dependent variable, had three parameters: Organization goals attainment, stakeholder satisfaction, and process efficiency. Leadership style, the independent variable, also had three parameters; clear instructions, concern for employees, and employee consultation. Leadership style, for this study, is defined as the attitude and behavior of a leader, particularly in relation to his or her colleagues and team members, expressed in various ways, these includes what a leader says, how they say it, the example they set, their body language, and their consistent behavior (Lussier \& Achua, 2013). The definition of organizational effectiveness, for purposes of this research, is the capability of the organization to meet its set vision and mission given the resources available (Yukl, 2008). The null hypothesis was: Leadership style does not significantly influence organizational effectiveness of NGOs in Kenya. The significance of this research is that it sought to raise ideas and issues in the hope that various stakeholders and leaders of NGOs, with a keenness on organizational effectiveness, will continue the discussion further. The study has contributed several practical areas for NGOs in their efforts to improve on their organizational effectiveness and leader's development.

\section{Literature Review}

\subsection{Path-Goal Theory}

Path-goal theory was originally developed by Martin G. Evans in the 1970s and later modified by Robert J. House in 1971 to identify a leader's most practiced style as a motivation to get subordinates to accomplish goals (Cote, 2017). House and Mitchell revised the Path-goal theory in 1974 (Cote, 2017). The path-goal theory presented two basic propositions as described by House and Mitchell. The first one is that the strategic function of the leader is to enhance the psychological state of subordinates, resulting in motivation to perform or in satisfaction with the job. The second is that particular situational leader behavior will cause subordinate motivation (Polston-Murdoch, 2013). There are four path-goal leadership styles that function to provide structure and/ or reward to subordinates; these are directive, supportive, participative, and achievement-oriented (Polston-Murdoch, 2013; Cote, 2017).

The directive leader gives clear instructions on the standard organization rules and process, with an organization's mission attainment as the end goal (Polston-Murdoch, 2013). This style is negatively related to subordinates' satisfaction for those performing the leadership roles, quite predictably. However, when a leader adopts the directive style, the behavioral style of the leader influences how the subordinates receive those instructions, hence their satisfaction. Furthermore, directive leadership style emphasizes giving direction to subordinates regarding their tasks (Cote, 2017). The dictates explain how a task is done, what factors or outcome will define its success, and the organization's standard operating procedures (Yukl, 2006). Where task ambiguity exists, the directive style offers a catalyst for subordinate motivation (Dubrin, 2013), and is often called task-oriented style (Daft, 2005; Cote, 2017).

Supportive leadership style leaders are approachable, friendly, and empathetic to their subordinates' wellbeing; subordinates who are unsure of themselves prefer this style (Yukl, 2006; Durbin, 2013). Participative leadership style seeks employee participation in decision making and using their ideas during the implementation of an organization's activities and processes (Daft, 2005). In addition, this style is suitable for boosting the morale of subordinates who perform non-repetitive ambiguous tasks (Dubrin, 2013). Achievement-oriented leaders set high performance targets and will continuously increase the standard once it met or staff is near to achieve (Daft, 2005). These leaders also express the capability of their staff and will seek such traits during recruitment (Yukl, 2006). Achievement oriented style is suitable where there are subordinates seeking high challenge impact assignments that are non-repetitive and vary in the context and process needed to complete them (Dubrin, 2013).

The path-goal theory is different from the trait theory in that leaders are not constrained to a leadership style that 
depends on their personality (Malik, 2012). Path-goal theory is different from contingency theory in that leaders do not have to be matched to particular situations or the situation changed to match leader style. Leaders may be flexible and exercise all or any or a blend of the four styles described above depending on the subordinate and task characteristics (Dubrin, 2013).

Several characteristics commonly determine how much satisfaction (present or future) subordinates will obtain from a leader's behavior. These are subordinates' needs for affiliation, preferences for structure, desires for control, and self-perceived level of task ability (Northouse, 2012). Task characteristics such as design, work groups and formal authority influence leader behavior and hence affect subordinates' satisfaction and motivation (Northouse, 2012). House's path-goal theory assumes leaders are flexible and adjust their style to meet the challenge of the situation (Polston-Murdoch, 2013).

Path-goal theory proposes that when subordinates perceive their superior's behavior as the source of satisfaction of their job, the leader's behavior is considered acceptable and can lead to the subordinate's satisfaction (Cote, 2017). Contentment and commitment to the supervisor positively correlated with loyalty to the supervisor and organizational commitment (Cote, 2017). Organization commitment is positively related to supervisory support, and subordinates will often leave an organization because of the leader or manager (Polston-Murdoch, 2013). The leader's behavior is acceptable only when subordinates perceive it as either an immediate or a future source of job satisfaction (Polston-Murdoch, 2013).

There are four main criticisms of the Path-goal theory by Northhouse (2012). First, path-goal theory limitation is complex, for it incorporates so many different aspects of leadership that interpreting the theory can be confusing. For example, predictions about which of four different leadership styles is appropriate for a task is dependent on the different structure, levels of goal clarity, followers' ability, and organization degrees of formal authority. Second, path-goal theory has received only partial support from the many empirical research studies testing its validity. Thirdly, Path-goal theory fails to explain adequately the relationship between leadership behavior and follower motivation. Finally, the theory suggests that it is important for leaders to provide coaching, guidance, and direction for followers, which may lead the followers to be overdependent on their leaders.

The Path-goal theory provides a useful theoretical framework for understanding how various leadership behaviors affect followers' satisfaction and work performance (Northhouse, 2012). This study considered three leadership style constructs from the theory: Clear instructions, concern for employees, and consultation. These three constructs as are offered as representing the four path-goal leadership styles stated as follows: directive, supportive, participative, and achievement oriented, discussed for the purpose of this study.

\subsection{General Systems theory}

The three major pioneers of general systems theory (GST) are Kenneth Boulding, Daniel Katz, and Robert Kahn (Amagoh, 2008). In addition, a system comprises of subsystems whose inter-relationships and interdependence move toward equilibrium within the larger system, according to Amagoh (2008), who goes on to say that a system is a set of two or more parts where the behavior of each will influence the behavior of the whole. Furthermore, the behavior of the parts and their effects are interdependent, so that while subgroups of the parts all influence the behavior of the whole, none of the subgroups has an independent effect on itself. General systems theory provides a distinction between open and closed systems (Shafritz \& Russell, 2005).

The general systems theory emphasizes boundary, environment, feedback and adaptive response. These emphases presume management is readily identified as the control center, creating a weakness since it overestimates a management team member's power to control events and actions (Beeson \& Davis, 2000). With systems theory, managers should focus on the role played by each part of an organization; rather than dealing separately with the parts, both interpersonal and group behavioral aspects leading to a system of cooperation is emphasized (Hannagan \& Bennett, 2008). The systems theory, though informative on an organization's internal process and its interaction with the outside environment, does not inform on behavior of the management of an organization, hence Path-goal theory grounds leadership style in this research. The systems theory provides a basis for three variables used in this study to assess organization effectiveness: Goal attainment, stakeholder satisfaction, and internal processes.

\subsection{Leadership Style and Organizational Effectiveness}

Recent research into NGO leaders in Africa highlights that they operate in three different worlds: The global aid world, the urban context in which they live and work, and the rural village setting where many of their extended families still live (James, 2005). Often, tight project schedules, over-hasty timeframes, and demands for quick results placed by donors add to the pressure faced by national NGO leaders (Kaplan, 2002). Researchers have 
examined the influence of hierarchical leadership in implementing strategies. O'Reilly et al. (2010) undertook research on the relationship between leadership alignment and strategy implementation in a large healthcare organization whose identity was kept anonymous. The research concluded that it was only when leaders' effectiveness at different hierarchical levels was considered that significant performance improvement occurred while implementing strategies.

A research to examine if servant leadership style influences work performance of the employees in Pakistani NGOs established that staff-work outcome influences an institution's productivity (Schneider \& George, 2010). Empowerment and employee motivation, it concluded plays a mediation role between leadership styles and employee performance (Schneider \& George (2010). This study provides an impetus to examine leadership influences on employees that then leads to organizational effectiveness given that NGOs focus on human welfare services, with social impact and personal goals providing a double motivation. Zaribaf and Hamid (2010), while studying the factors affecting implementation of strategic plans in Pasargad Bank branches in Tehran, Iran, categorized the importance of leadership into three key roles: Compliance to organization procedures, relationship-building, and staff development.

Rajasekar (2014), in a research studying strategy implementation in electricity distribution companies in the Sultanate of Oman, in Asia, found that leadership was more significant in influencing successful implementation strategy in the service sector. The study focused on several factors and revealed the influence of leadership (37 percent), culture (28 percent), organization structure ( 26 percent) and systems ( 9 percent). A research on the impact of academic leadership on faculty motivation and organizational effectiveness in the higher education system, in Pakistan, had leadership as the independent variable, motivation as a moderating variable and organizational effectiveness as a dependent variable (Siddique, Aslam, Khan and Fatima, 2011). The findings showed that academic leadership was different from that of other organizations, for example the manufacturing sector. The study's limitation was that the sub-variables chosen did not depict the leadership construct in strategy implementation, and therefore attributes such as style, traits, characteristics and personality were not studied. The sub-variables of leadership were research, education and administration.

In 1985, researcher Bernard Bass contributed more to Burns' theory by stating that leaders succeed by gaining the trust, respect and admiration of their followers (Allen, Smith \& Silva, 2013). In a research on the effect of leaders' styles of decision-making on perceived organizational effectiveness in higher education institutions in Khyber Pakhtunkhwa in Pakistan, Hassan, Shah, Zaman, Ikramullah and Shah (2011) made it clear that the rational or collegial style of decision-making positively influences organizational effectiveness, whereas the autocratic or political style of decision making negatively influences organizational effectiveness. A research on Zimbabwe's state-owned enterprises concluded that great strategy implementation is negatively correlated to low leadership involvement (Mapetere, Mavhiki, Tonderai, Sikomwe, \& Mhonde, 2012).

Charismatic leadership influences perceptual performance outcomes, for example a positive work attitude by staff and a firm's profitability, but this is unrelated to organization liquidity and solvency in conditions of environmental uncertainty (Hoogh et al., 2004). The research was on charismatic leadership, environmental dynamism, and performance in small and medium-sized organizations in the Netherlands.

Boehnke, Bontis, DiStefano and Stefano (2003) focused on a global petroleum company and examined examples of outstanding organizational performance provided by employees to pinpoint what leadership attributes have contributed to the outcomes. The results indicated that transformational leadership characteristics resulted in high performance. A research conducted in Ghana reviewed whether a firm's performance was influenced by leadership styles and had autocratic, democratic and laissez-faire leadership styles as the independent variables, with the dependent variable being financial performance (Puni, Samuel, \& Okoe, 2014). The findings showed that the democratic leadership style was more associated with high financial performance and sustainability than autocratic and laissez faire leadership styles (Puni et al, 2014). Further south in Zimbabwe, Martin, Nyasha and Edson (2014) studied leadership styles and organizational performance in a case study of LG finances in the town of Bindura. The analysis revealed that the autocratic leadership style used by the managers influenced junior staff negatively, leading to low individual and organizational performance. Other factors affecting performance of the firm, besides its leadership style, were poor employee performance, poor motivational strategies, reduced staff morale, and unavailability of resources (Martin et al., 2014).

In a research in Nigeria, the researchers Obiwuru, Okwu, Akpa and Nwankwere (2011) focused on transactional and transformational leadership styles. The transformational leadership and performance components studied were charisma, inspirational motivation and intellectual stimulation, or individual consideration. The conclusion was that transactional leadership components and performance variables constituted constructive or contingent 
rewards and were corrective or worked through management by exception, in response to performance effort, productivity and loyalty, respectively. Transactional leadership style is more appropriate in inducing performance in small-scale enterprises than transformational leadership style (Obiwuru et al., 2011). For growth and transition to transformational leadership style as the enterprises developed, grew and matured, the management needed to develop the transition strategies (Obiwuru et al., 2011). While studying factors that affect strategy implementation in NGOs in Kenya, Abok (2013) concluded that NGO leaders often face extraordinary challenges both at a personal and organizational level and that four major factors that impact efficiency in implementation of strategic plans are tangible and intangible assets; organization information flow and repository; culture, leadership style and stakeholders.

Following the theoretical framework and empirical studies discussed, this study expected leadership style constructs to influence organizational effectiveness. Therefore, this study's null hypothesis was:

H0: Leadership style does not significantly influence organizational effectiveness of NGOs in Kenya.

\section{Methodology}

The research adopted the positivistic approach as a study philosophy, using both explanatory and descriptive research design. To find out the influence of leadership style on organizational effectiveness, the study adopted the positivistic approach and relied mainly on quantitative data.

This study took on a deductive approach because it aimed to investigate and make a prediction of the influence of leadership style on the organizational effectiveness of NGOs in Kenya based on the hypothesis, with a view to reaching a logical conclusion. A deductive approach was chosen because this study moves from the broad construct of the independent variable being leadership style and dependent variable as organization effectiveness, to the narrower three parameters tested for each variable. The descriptive design was adopted due to its usefulness in studies to test the relationship between variables in a population. The explanatory research design was suited for the study since it sought to explain how a change in the independent variable affects the dependent variable.

\subsection{Population and Sample}

The study population comprised Kenyan registered non-governmental organizations. The study focused on project managers of NGOs registered in Kenya. The population was 5547 NGO project managers of NGOs registered with the Non-Governmental Organizations Co-ordination Board as at October 2016. In Kenya, the NGOs Coordination Board is responsible for registering, facilitating and coordinating all national and international NGOs operating in the country. Sample size was calculated using Yamene formula. Simple random sampling technique was implemented to draw out the sample size of as 374 project managers from the total population. The study used simple random sampling to identify the NGOs for data collection. Simple random sampling reduced bias and gave each NGO a chance to participate. The choice of project managers was informed by the fact that they are the ones in leadership, are responsible for strategy implementation and are best placed to provide the information for this study.

\subsection{Validity and Reliability}

The questionnaires used a 5-likert scale. The questions were a mix of closed and open-ended questions that offered a chance for additional explanations or context clarification by respondents. The researcher sought a letter of authorization to carry out research from USIU-A and also the National Commission for Science, Technology and Innovation (NACOSTI), whose mandate is to regulate and assure quality in the science, technology and innovation sector research. The construct validity of the questionnaire was informed by a review done by the research supervisors, and prior similar studies were used to improve on the validity of the research instrument. The questionnaire was also reviewed by experts in research at the USIU-Africa research office and the NGO industry. A pilot study was done to validate the reliability and validity of the questionnaire and ensure that the research instrument was working properly. After the pilot test, modifications were made in the questionnaire to reduce the possibility of ambiguity of questions and increase the reliability and validity of the questionnaire. The Cronbach's alpha analysis was done to measure the internal consistency of the likert scale questions. The questionnaire was reliable with Cronbach's alpha for leadership style value at 0.706 and organizational effectiveness at 0.838 , which is above the acceptable values indicated by Tavakol and Dennick (2011) of alpha range from 0.70 to 0.95 .

\subsection{Ethics and Research Procedures}

The ethical consideration done was anonymity and confidentiality of the respondents, and professional engagement of respondents was done. To be compliant with the government's policy on research, permission to 
carry out the study was also sought from NACOSTI. This assured the respondents that the research was purely for academic purpose. The questionnaires with missing data were reviewed at collection stage and each respondent was requested to fill them completely, as the research procedure used was pick and drop.

\subsection{Prerequsite Tests and Model}

The data coding and prerequisite analysis for regression tests that is normality test, Kolmogorov-Smirnov test, multi-collinearity test, heteroscedasticity and test for linearity were done, followed by descriptive and inferential analysis. The date met the prerequisite tests. The linear equation model was stated as:

$$
Y=\beta 0+\beta 1 X 1+\beta 2 X 2+\beta 3 X 3+e
$$

Where,

$\mathrm{Y}=$ Organizational effectiveness ( made up of three parameters, organization goals attainment, stakeholders' satisfaction and process efficiency)

$\beta=$ constant value

$\mathrm{X} 1=$ clear instructions

$\mathrm{X} 2=$ concerns for employees

$\mathrm{X} 3=$ employee consultation

$\mathrm{e}=$ error term.

\section{Analysis and Findings}

The null hypothesis; leadership style does not significantly influence organizational effectiveness, was tested in this section. The demographic results are in Table 1.

Table 1. Demographic results

\begin{tabular}{llc}
\hline Demographic Variables & Results & \\
\hline Gender of the respondents & Male $=53 \%$ & \\
Availability of a Written Strategic Plan & Female $=47 \%$ & \\
& Yes $-91.3 \%$ & \\
Frequency of Strategic Plan Review & No $-8.7 \%$ & Percent \\
& Length & 64.5 \\
& After 1-2 years & 10.0 \\
& After 3-4 years & 25.5 \\
& After 5 years & Percent \\
Actors in charge of Strategy Implementation & Who & 27.6 \\
& Everybody & 24.7 \\
& Special implementation unit & 1.8 \\
& External experts/consultants & 1.8 \\
& Myself & 40.4 \\
& Select management team & 3.6 \\
\hline
\end{tabular}

The response rate for the study was 73.5 percent. The results of the gender spread had majority of the respondents as male at 52.7 percent and female at 47.3 percent. This shows that most of the project managers were male. The male majority is explained by the fact that NGOs tend to have social and at times physically-straining assignments, especially those serving remote areas in Kenya, hence having a masculine preference.

The results show that 91 percent of the organizations have a strategic plan, while only 9 percent do not have one. This shows that strategy plan development in the NGO sector has improved. The high uptake, with 91.3 percent of NGOs having a written plan, is attributed to the general acceptance of strategic planning practice by both the public and private sectors in Kenya. The minority that do not have a written document, at 9 percent of NGOs, on follow up informed the researcher that they have a strategy; however, this is mainly known to the NGO founders and top leadership and does not exist in a formal written document. Most of such NGO founders preferred to protect their organizations by having their strategies known to only a few select individuals. 
The results indicate that most of the respondents, at 64.5 percent, review their strategy plans after one to two years, whereas 10 percent said three to four years, and 25.5 percent after five years. This indicates the volatility of the NGO sector and the need to keep aligning strategy plans with the environment regarding sources of funds to ensure sustainability and execution of missions.

From the results, most of the project managers, at 40.4 percent, indicated that a select management team is responsible for strategy implementation, and the second highest selected option at 27.6 percent stated that everybody was involved in strategy development. This is supported by the norm, where a select team does the funding proposals; only after funding is received is the full project team hired. This then means that a majority of those implementing projects find the project work plan and strategy already laid out by the time they are employed and are possibly consulted when implementing sub-activities.

\subsection{Descriptive Statistics of Leadership Style}

Leadership style was defined in terms of clear instructions, concern for employees, and consultations between employees. The standard deviation shows how close to the mean the respondents' data is and a large standard deviation means that the values in the data set are farther away from the mean, with variation showing the degree of dispersion among data collected. Variances with large values represent greater dispersion.

The mean for leadership style ranged from 2.72 to 4.43 . The findings of the study indicate that leadership style influences organizational effectiveness; hence, Kenyan NGOs utilize the leadership styles to enhance organizational effectiveness. Even though the study shows that respondents agreed that most of the variables of leadership style enhance organizational effectiveness, they highly disagreed on the fifth variable, that concern for employees enhances organizational process efficiency, hence the lowest mean of 2.27. The study depicts that the standard deviation for leadership style and organizational effectiveness ranged from 0.848 to 1 . 424.The findings indicate that most respondents agreed that clear instructions enhance the satisfaction of the stakeholders. The study reveals that respondents had varied opinions on the statement that concern for employees enhances organizational process efficiency, hence the highest standard deviation of 1.424 .

\subsection{Regression Analysis of Leadership Style and Organizational Effectiveness}

To determine the influence of leadership style on organizational effectiveness of NGOs, a linear regression was used on the data, with the dependent variable being the mean score of the leadership style variable and the independent variable being the mean score of organizational effectiveness. Table 2 below summarizes the model fit of the regression model.

Table 2. Model summary of leadership style and organizational effectiveness

\begin{tabular}{llllll}
\hline Model & R & R Square & Adjusted R Square & Std. Error of the Estimate & Durbin-Watson \\
\hline 1 & $0.393^{\mathrm{a}}$ & 0.154 & 0.151 & 0.50452 & 1.727 \\
\hline
\end{tabular}

a. Predictors: Leadership Style.

b. Dependent Variable: Organizational Effectiveness.

The results indicate an R square of 0.151 . This means that the linear regression model explains 15.4 percent of the data, i.e. leadership style causes 15.1 percent variation in the outcome of the dependent variable, organizational effectiveness. The 84.9 percent is accredited to the error term and variables not examined in this research.

Analysis of Variance (ANOVA) was used to test the null hypothesis, that the model with leadership style as an independent variable explains zero variance in organizational effectiveness. Table 3 below displays the results of the ANOVA test for leadership style and organizational effectiveness.

Table 3. ANOVA test of leadership style and organizational effectiveness

\begin{tabular}{|c|c|c|c|c|c|c|}
\hline \multicolumn{7}{|c|}{ ANOVA ${ }^{a}$} \\
\hline \multirow{4}{*}{$\frac{N_{1}}{1}$} & & Sum of Squares & Df & Mean Square & $\mathrm{F}$ & Sig. \\
\hline & Regression & 12.695 & 1 & 12.695 & 49.875 & $0.000^{\mathrm{b}}$ \\
\hline & Residual & 69.489 & 273 & 0.255 & & \\
\hline & Total & 82.183 & 274 & & & \\
\hline
\end{tabular}

a. Dependent Variable: Organizational Effectiveness.

b. Predictors: Leadership Style. 
The F-Statistic from ANOVA test explained the overall significance of the regression model at 95 percent confidence interval. The criteria for rejecting the null hypothesis was to reject the null hypothesis if the p-value of the F-Statistic was less than the $\mathrm{p}$-value at 95 percent confidence level $=0.05$. The results indicated that the calculated F-Statistic $=49.875$ and a $p$-value $=0.00<0.05$. Hence, the null hypothesis was rejected and the model with leadership style as an independent variable explains some variance in organizational effectiveness. Table 4 below shows the coefficients of variation of leadership style and organizational effectiveness.

Table 4. Detailed coefficient of leadership style and organizational effectiveness

\begin{tabular}{|c|c|c|c|c|c|c|c|}
\hline & \multicolumn{2}{|c|}{$\begin{array}{l}\text { Unstandardized } \\
\text { Coefficients }\end{array}$} & \multirow{2}{*}{$\begin{array}{l}\text { Standardized } \\
\text { Coefficients }\end{array}$} & \multirow{2}{*}{$\mathrm{t}$} & \multirow[t]{2}{*}{ Sig. } & \multicolumn{2}{|c|}{$\begin{array}{l}\text { Collinearity } \\
\text { Statistics }\end{array}$} \\
\hline & $\mathrm{B}$ & Std. Error & & & & Tolerance & VIF \\
\hline (Constant) & 3.097 & 0.217 & & 14.276 & 0.000 & & \\
\hline $\begin{array}{l}\text { Clear instructions support the attainment of } \\
\text { organizational goals }\end{array}$ & 0.127 & 0.038 & 0.219 & 3.295 & 0.001 & 0.632 & 1.582 \\
\hline $\begin{array}{l}\text { Clear instructions enhance the satisfaction of } \\
\text { stakeholders }\end{array}$ & 0.017 & 0.048 & 0.026 & 0.348 & 0.728 & 0.507 & 1.973 \\
\hline Clear instructions ensure process efficiency & 0.011 & 0.046 & 0.017 & 0.229 & 0.819 & 0.525 & 1.905 \\
\hline $\begin{array}{l}\text { Concern for employees facilitates the } \\
\text { attainment of organization goals }\end{array}$ & 0.101 & 0.038 & 0.176 & 2.642 & 0.009 & 0.629 & 1.591 \\
\hline $\begin{array}{l}\text { Concern for employees ensures that } \\
\text { stakeholders are satisfied }\end{array}$ & -0.082 & 0.029 & -0.156 & -2.775 & 0.006 & 0.881 & 1.135 \\
\hline $\begin{array}{l}\text { Concern for employees enhances } \\
\text { organizational process efficiency }\end{array}$ & -0.055 & 0.021 & -0.144 & -2.623 & 0.009 & 0.922 & 1.084 \\
\hline $\begin{array}{l}\text { Consultations between employees and leaders } \\
\text { facilitate goal attainment }\end{array}$ & 0.019 & 0.034 & 0.033 & 0.554 & 0.580 & 0.766 & 1.305 \\
\hline $\begin{array}{l}\text { Employee consultation enhances stakeholder } \\
\text { satisfaction }\end{array}$ & 0.046 & 0.037 & 0.092 & 1.263 & 0.208 & 0.524 & 1.909 \\
\hline $\begin{array}{l}\text { Consultations within the organization ensure } \\
\text { process efficiency }\end{array}$ & 0.05 & 0.035 & 0.09 & 1.424 & 0.156 & 0.694 & 1.44 \\
\hline
\end{tabular}

Two constructs are significant and have positive coefficients: Instructions support the attainment of organizational goals at 0.219 , while concern for employees facilitates the attainment of goals at 0.176 . Two constructs are significant and have negative coefficients: Concern for employees ensures that stakeholders are satisfied at -0.156 and enhances organizational process efficiency at -0.144 . Five constructs are not significant and have positive coefficients. These are that consultations between employees and leaders facilitate goal attainment; employee consultation enhances stakeholder's satisfaction; consultations within the organization ensure process efficiency; instructions enhance the satisfaction of stakeholders; and instructions ensure process efficiency.

The variable leadership style effect on organizational effectiveness, linear equation model is stated as:

Where,

$$
Y=\beta 0+\beta 1 \mathrm{X} 1+\beta 2 \mathrm{X} 2+\beta 3 \mathrm{X} 3+\beta 4 \mathrm{X} 4+\beta 5 \mathrm{X} 5+\beta 6 \mathrm{X} 6+\beta 7 \mathrm{X} 7+\beta 8 \mathrm{X} 8+\beta 9 \mathrm{X} 9+\mathrm{e}
$$

$\mathrm{Y}=$ organizational effectiveness,

$\beta=$ constant value,

$\mathrm{X} 1=$ clear instructions and organization goal attainment

$\mathrm{X} 2=$ clear instructions and stakeholder satisfaction

$\mathrm{X} 3=$ clear instructions and process efficiency

$\mathrm{X} 4=$ concerns for employees and organization goal attainment

$\mathrm{X} 5=$ concerns for employees and stakeholder's satisfaction

$\mathrm{X} 6=$ concerns for employees and process efficiency

$\mathrm{X} 7=$ consultations and organization goal attainment 


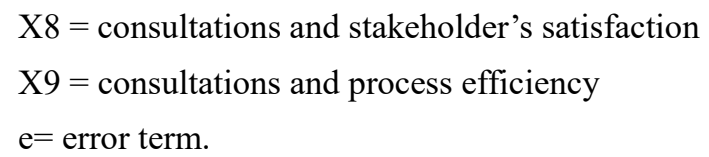

The detailed coefficients thus represent organizational effectiveness as,

Organizational Effectiveness $=3.097+0.219 X 1+0.176 X 4-0.156 X 5-0.144 X 6+$ error term

\section{Discussion, Conclusion and Recommendation}

\subsection{Discussion of the Findings}

This study examined how leadership style influences organizational effectiveness of NGOs in Kenya. The results indicate that leadership style significantly influences organizational effectiveness. This result was achieved using ANOVA. The regression coefficient shows that leadership style positively and significantly influences the achievement of organizational effectiveness.

The first parameter of the research was the influence of clear instructions on goal attainment. The results showed a positive significant influence. This finding echoes the findings of Kaplan (2002), who found that unclear instructions from donors bring about tight project schedules, quick results and over-hasty timeframes that cause a lot of pressure on NGOs, hence affecting their productivity. The finding of this study also mirrors that of O'Reilly et al. (2010), who observed that clear instructions in an organization enhance organizational goal attainment. The authors in that study found that leaders' effectiveness at different hierarchical levels significantly enhanced organizational performance. It was further revealed that leadership type affects clarity of information, empowering and motivating employees to perform their tasks as instructed by their leaders.

This research's second parameter was the influence of clear instructions on satisfaction of stakeholders. The results indicate a not-significant influence. The results of Siddique et al. (2011) differ, for they found that types of leadership have different performance in different organizations. The authors revealed that the leadership types in academic institutions perform differently from the leadership types in other sectors like manufacturing. Hassan et al. (2011), confirms the findings of Siddique et al. (2011) by revealing that in education institutions, a rational style of decision-making positively influences organizational effectiveness, whereas an autocratic style of decision making negatively influences organizational effectiveness. This research reveals that clear instructions from leadership enhances the leadership involvement in strategy implementation and that low leadership involvement in strategy implementation as found by Mapetere (2012) leads to partial strategy success in an organization.

In the third parameter, the influence of clear instructions on process efficiency was examined; the results indicate a not-significant influence. This study does not support the findings of Martin et al. (2014) who posited that poor employee motivational strategies, reduced staff morale and unavailability of resources significantly hinder process efficiency in organizations. The authors in the said study revealed that for organizations to achieve effectiveness in their processes, they need to employ a leadership style that would adopt better strategies for employee motivation, enhance staff morale and effectively allocate organizational resources. Lussier and Achua (2013) reveal that leadership is a process in which an individual influences a group of individuals to achieve a common goal and that effective leadership sends clear instructions to followers that make the process of achieving a goal more efficient. To confirm the findings of the study, Kippenberger (2002) states that what a leader says, how he says it, the example he sets, his body language and his general conduct and character significantly affect the efficiency of the organizational processes. Northouse (2012) found that leadership is a process that involves influence, occurs in a group context, and involves goals attainment. To attain goals effectively, the study confirmed that leadership should provide efficient processes that would guide the staff in pursuing their tasks.

This study in the fourth parameter tested concerns for employees and attainment of organizational goals. The results indicate a positive significant influence. The findings of the study support the findings of McCleskey (2014), who found that leaders and followers together advance to a higher level of morality and motivation to benefit the organization and individuals when the leaders are concerned about employees. Morever, it is also echoed by Avolio and Bass (2002), who assert that when leaders are more concerned about followers, they succeed by gaining the respect, trust and admiration of their followers. They further posit that transformational leadership is more concerned about followers than other leadership types because of its charisma, inspiration, intellectual stimulation, individualized consideration, and contingent reward, hence facilitating the attainment of goals. 
This study in the fifth parameter tested the influence of concern for employees in ensuring stakeholders are satisfied; the results indicate a significant negative influence. The findings are supported by Avolio and Bass (2002), who found that a leadership type that challenges the status quo and proceeds to inspire creativity and new ways of doing things significantly satisfies organizational stakeholders. Lussier and Achua (2013), on their part, confirmed that individualized consideration where the leaders support their followers by ensuring transparency, open communication, and that followers are given a chance to voice their ideas ensures that an organization achieves its goals.

This study in the sixth parameter tested the influence of concern for employees on enhancing organizational process efficiency; the results indicate a significant negative influence. This study found that management concern for employees negatively and significantly enhances organizational process efficiency. The finding by Boehnke et al. (2003) differs since leaders' concern for their employees positively influenced achievement of an organization's goals. Hence, this study makes a significant contribution in finding that in NGOs in Kenya, leadership concern for employees will negatively enhance process efficiency, sometimes leading to overlooking the performance results expected of an employee as stated in the open-ended questions on leadership construct.

The study in the seventh parameter tested the relationship between leadership consultative style and organization goal attainment; the results indicate a non-significant influence. This is different from the study by Boehnke et al. (2003), which revealed that consultations between employees and leaders significantly facilitate goal attainment. The difference is seen also in the findings of Allen et al. (2013), who asserted that consultation between employees and leaders ensure that the path to goal attainment is clearly understood by internal actors, removes potential barriers within the system, and motivates the staff to achieve the predetermined goals.

This study in the eighth parameter tested the relationship between leadership consultative style and stakeholder satisfaction; the results indicate a non-significant influence. The study found that different leadership styles have different achievements. This confirms the study by Puni et al. (2014), who did a study on the effect of different leadership styles on the financial performance of Ghanaian banks. The findings were that the democratic leadership style is more associated with high financial performance and sustainability than autocratic and laissez faire leadership styles.

This research, in the ninth parameter, tested the influence of leadership consultative style on process efficiency. The results indicate a non-significant relationship between consultative style and process efficiency. The study differs from the findings of Hoogh et al. (2004), who asserted that charismatic leadership influences performance, and observed that when all employees have positive work attitudes they tend to perform their tasks to fulfill organizational objectives. This is a unique contribution of this study given the context of the NGO sector.

Generally, this study tested the relationship between leadership style and organizational effectiveness. The study overall findings support Rajasekar (2014), who stated that leadership style significantly affects organizational effectiveness. He argues that the top management must emphasize the various interfaces within the organization, and that the key challenge to successful strategy implementation is in ensuring that employees buy into and direct their capabilities and business understanding toward the new strategy.

\subsection{Conclusion}

From the findings, the researcher concludes that the research explains the nature of relationship between leadership style and organizational effectiveness. It is concluded that leadership style significantly influences organizational effectiveness, a finding that is supported using ANOVA. The regression coefficient shows that leadership style positively and significantly influences the achievement of organizational effectiveness. This study also found that leadership style significantly correlates and influences organizational effectiveness. These findings led to the conclusion that leadership style significantly influences organizational effectiveness. This research determines that to attain organizational goals, enhance the satisfaction of stakeholders, and ensure organizational process efficiency, leaders and managers must provide distinct, specific instructions. Concern for employees facilitates the attainment of goals, ensures that stakeholders are satisfied, and enhances organizational efficiency. The study also concludes that consultation between employees and leaders facilitates goal attainment, enhances stakeholder satisfaction, and ensures organizational process efficiency. The results led to rejection of the null hypothesis that leadership style does not significantly influence the organizational effectiveness of NGOs in Kenya.

\subsection{Recommendation}

The study recommends that NGOs use a leadership style that provides clear instructions to employees to enhance attainment of organizational goals. The study identified concern for employees, and consultations between 
employees and leaders, as the factors of leadership style that significantly influence organizational effectiveness. The study recommends that management and concerned parties should ensure that employee welfare is given priority to facilitate the attainment of organizational goals. Concern for employees also enhances organizational process efficiency. Therefore, consulting employees on matters concerning the organization's strategy helps in attaining organizational goals, and failure to address these issues would lead to organizational ineffectiveness.

Based on the findings of this study, other leadership theories should be examined to increase the parameters of leadership styles studied, since this study examined only three. There is also a need for further studies to determine the effect of the national political environment as a mediator variable, given its influence on NGO leadership especially those in the civil-society sector.

\section{References}

Abok, A. M. (2013). Factors affecting effective implementation of strategic plans in non- governmental organizations in Kenya. (Unpublished PhD thesis). Jomo Kenyatta University of Agriculture and Technology, Kenya. Retrieved

from http://ir.jkuat.ac.ke/bitstream/handle/123456789/1305/Dr_Abok_Alice_Mwajuma_PhD_JKUAT_2013.pdf? sequence $=1$ \&isAllowed $=y$

Allen, S. L., Smith, J. E., \& Silva, N. D. (2013). Leadership style in relation to organizational change and organizational creativity: Perceptions from nonprofit organizational member. Nonprofit Management and Leadership, 24, 23-42. https://doi.org/10.1002/nml.21078

Amagoh, F. (2008). Perspectives on organizational change: systems and complexity theories. The Innovation Journal: The Public Sector Innovation Journal, 13(3), 1-14. Retrieved from http://www.innovation.cc/scholarly-style/amagoh3dec2008jag2rev1.pdf

Bagire, V., Aosa, E., \& Awino, Z. B. (2012). The strategy resource configurations and performance implications in non-governmental organizations. Crown Research in Education, 2(3), 105-112, Retrieved from $\mathrm{https} / / /$ profiles.uonbi.ac.ke/sites/default/files/the_interaction_of_personal_factors_structure_and_performan ce in_ngos_0.pdf

Beeson, I., \& Davis, C. (2000). Emergence and accomplishment in organizational change. Journal of Organizational Change Management, 13(2), 178-189. https://doi.org/10.1108/09534810010321508

Boehnke, K., Bontis, N., DiStefano, J. J., \& DiStefano, A. C. (2003). Transformational leadership: An examination of cross-national differences and similarities. Leadership and Organization Development Journal, 24(1), 5-15. https://doi.org/10.1108/01437730310457285

Cote, R. (2017) A comparison of leadership theories in an organizational environment. International Journal of Business Administration, 8(5), 28-35. https://doi.org/10.5430/ijba.v8n5p28

Daft, R. L. (2010). Organization theory and design (10th ed). South Western: Cengage Learning.

David, F. R. (2011). Strategic management: concepts and cases (13th ed.). New Jersey: Prentice Hall.

Dubrin, A. J. (2013). Leadership: Research findings, practice, and skills. Boston: Cengage Learning.

Feo, J. A., \& Janssen, A. (2001). Implementing a strategy successfully. Measuring Business Excellence, 5(4), 4-6. https://doi.org/10.1108/13683040110411223

Ferreira, M. R., \& Proenca, J. F. (2015). Strategic planning and organizational effectiveness in social service organizations in Portugal. Management, 20(2), 1-21. Retrieved from https://hrcak.srce.hr/150562

Green, D. (2015), Fit for the future: Development trends and the role of INGOs. Oxfam, Oxford. Retrieved from http://www.globaltfokus.dk/images/Kapacitetsudvikling/Arrangementer_kap_forum/dp-fit-for-future-INGO s-110615-Oxfam-en.pdf

Hannagan, T., \& Bennett, R. (2008). Management: Concepts \& practices (3rd ed.). Financial Times: Prentice Hall.

Hassan, F. S., Shah, B., Zaman, T., Ikramullah, M., \& Shah, A. I. (2011). Effect of leaders' styles of decision making on perceived organizational effectiveness: An example from Pakistan. International Journal of Business and Social Science, 2(22), 297-307. Retrieved from http://ijbssnet.com/journals/Vol_2_No_22_ December_2011/34.pdf

Hoogh, A. H. B., Hartog, D. N., Koopman, P. L., Thiery, H., Berg, P. T., Weide, J. G., \& Wilderon, C. P. M. (2004). Charismatic leadership, environmental dynamism, and performance. European Journal of Work and 
Organizational Psychology, 13(4), 447-471. https://doi.org/10.1080/13594320444000164

James, R. (2005). The crushing impact of HIV/AIDS on leaders in Malawi, Praxis Note No.10, Oxford: INTRAC Retrieved from https://www.intrac.org/resources/praxis-note-10-crushing-impact-hivaids-leadership-malawi/

Johnson, G., Scholes, K., \& Whittington, R. (2008). Exploring corporate strategy (8th ed.). Prentice Hall.

Kaplan, A. (2002). Development practitioners and social process: Artists of the Invisible. London: Pluto Press.

Lussier, R. N., \& Achua, C. F. (2013). Effective leadership (5th ed.). USA: Southwestern Cengage Learning.

Malik, S. H. (2012) A study of relationship between leader behaviors and subordinate job expectancies: A path-goal approach. Pakistan Journal of Commerce and Social Sciences, 6(2), 357-371. Retrieved from http://www.jespk.net/publications/97.pdf

Mapetere, D., Mavhiki, S., Tonderai, N., Sikomwe, S., \& Mhonde, C. (2012). Strategic role of leadership in strategy implementation in Zimbabwe's state owned enterprises. International Journal of Business and Social $\begin{array}{lllll}\text { Science, } & 3(16), & 271-276 . & \text { Retrieved } & \text { from }\end{array}$ http://ijbssnet.com/journals/Vol_3_No_16_Special_Issue_August_2012/29.pdf

Martin, C., Nyasha, M., \& Edson, V. (2014). Leadership styles and organizational performance: A case study of LG finances, Bindura, Zimbabwe. International Journal of Innovative Research and Development, 3(6), 145-151. Retrieved from http://www.ijird.com/index.php/ijird/article/viewFile/50755/41289

Northouse, P. (2012). Leadership: Theory and practice (6th.ed). Thousand Oaks, CA: Sage Publications.

Obiwuru, T. C., Okwu, A. T., Akpa, V. O., \& Nwankwere, I. A. (2011). Effects of leadership style on organizational performance: A survey of selected small scale enterprises in Ikosi-Ketu council development area of Lagos State, Nigeria. Australian Journal of Business and Management Research, 1(7), 100-111. Retrieved from http://www.ajbmr.com/articlepdf/ajbmr_17_16i1n7a11.pdf

Okorley, E. L., \& Nkrumah, E. E. (2012). Organizational factors influencing sustainability of local Non-governmental organizations. International Journal of Social Economics, 39(5), 330-341. https://doi.org/10.1108/03068291211214190

Olanipekun, W. D., Abioro, M. A., Akanni, L. F., Arulogun, O. O., \& Rabiu, R. O. (2015). Impact of strategic management on competitive advantage and organizational performance evidence from Nigerian Bottling Company. Journal of Policy and Development Studies 9(2), 185-198. Retrieved from https://www.arabianjbmr.com/pdfs/JPDS_VOL_9_2/16.pdf

O'Reilly, C. A., Caldwell, D, F., Chatman, J. A., Lapiz, M., \& Self, W. (2010). How leadership matters: The effects of leaders' alignment on strategy implementation. Leadership Quarterly, 21(1), 104-113. https://doi.org/10.1016/j.leaqua.2009.10.008

Pearce, J., \& Robinson, R. (2013). Strategic management: Strategy formulation implementation and control (13th ed.). New York: McGraw-Hill//rwin.

Polston-Murdoch, L. (2013) An Investigation of path-goal theory, relationship of leadership style, supervisor-related commitment, and gender. Emerging Leadership Journeys, 6(1), 13- 44. Retrieved from https://www.scribd.com/document/173025935/An-Investigation-of-Path-Goal

Puni A., Ofei, S. B., \& Okoe, A. (2014). The effect of leadership styles on firm performance in Ghana. International Journal of Marketing Studies, 6(1), 177-185. http://dx.doi.org/10.5539/ijms.v6n1p177

Rajasekar, J. (2014). Factors affecting effective strategy implementation in a service industry: A study of electricity distribution companies in the Sultanate of Oman. International Journal of Business and Social Science, 59(1), 169-183. Retrieved from http://ijbssnet.com/journals/Vol_5_No_9_1_August_2014/15.pdf

Ramadan, M. A. (2015). The impact of strategy implementation drivers on projects effectiveness in non-governmental organizations. International Journal of Academic Research in Management, 4(2), 35-47. Retrieved from https://pdfs.semanticscholar.org/569c/fc44989e 71e1802c2ead80bbb7c6ee4f4736.pdf

Schneider, S. K., \& George, W. M. (2010). Servant leadership versus transformational leadership in voluntary service organizations. Journal of Leadership \& Organizational development, 30(1), 60-77.

Shafritz, J., \& Russell, E. (2005). Introducing public administration. New York: Pearson Longman.

Siddique, A., Aslam, H. D., Khan, M., \& Fatima, U. (2011). Impact of academic leadership on faculty's motivation, and organizational effectiveness in higher education system. International Journal of Business and Social 
Science, $\quad 2(8), \quad$ Retrieved $\quad$ from http://www.ijbssnet.com/journals/Vol._2_No._8\%3B_May_2011/23.pdf

Tavakol, M., \& Dennick, R. (2011). Making sense of Cronbach's Alpha. International Journal of Medical Education, 27(2), 53-57. http://dx.doi.org/10.5116/ijme.4dfb.8dfd

Teegen H., Doh, J., \& Vachani, S. (2004). The importance of nongovernmental organizations (NGOs) in global governance and value creation: an international business research agenda. Journal of International Business Studies, 35, 463-483. https://doi.org/10.1057/palgrave.jibs.8400112

Yukl, G. (2006). Leadership in organizations; Global edition (7th ed.). New York: Pearson.

Yukl, G. (2008). How leaders influence organizational effectiveness. The Leadership Quarterly, 19(6), 708-722. https://doi.org/10.1016/j.leaqua.2008.09.008

Zaribaf, M., \& Hamid, B. (2010). An effective factors pattern affecting implementation of strategic plans. Academic and Business Research Institute. Retrieved April 16, 2016, from http://www.aabri.com/LV2010Manuscripts/ LV10116.pdf

\section{Copyrights}

Copyright for this article is retained by the author(s), with first publication rights granted to the journal.

This is an open-access article distributed under the terms and conditions of the Creative Commons Attribution license (http://creativecommons.org/licenses/by/4.0/). 